\title{
Yield Gap Analysis of Jeeraphool Rice in Batauli Block of Surguja
}

\author{
Ravindra Tigga ${ }^{1}$ and Satyapal Singh $^{2} *$ \\ ${ }^{1}$ Krishi Vigyan Kendra, Ambikapur, District-Surguja, India \\ ${ }^{2}$ Department of Genetics and Plant Breeding, College of Agriculture, Raipur \\ Indira Gandhi Krishi Vishwavidyalaya, Raipur, Chhattisgarh-492012, India
}

*Corresponding author

\section{Keywords}

Aromatic rice,

Jeeraphool rice,

Surguja, Yield gap

Article Info

Accepted:

10 November 2018

Available Online:

10 December 2018

\section{A B S T R A C T}

Most of the farmers with extensive poverty in Surguja dominated by rainfed ecologies where rice is the principal source of staple food, employment, and income for the rural population. Success has been limited in increasing productivity in rainfed rice systems. The study based on primary as well as secondary data was carried out in Nine selected villages of batauli block of Surguja district of Chhattisgarh. Primary data were collected from a sample of 30 farmers spread over the study area, constituting 10 marginal, 15 small and 5 big farmers who were selected using probability proportional to size method for the study. The total Yield Gap in rice production was worked out as the summation of Yield Gap I and Yield Gap-II, which was estimated as $6.75 \mathrm{q} / \mathrm{ha}$ on big size, $9.55 \mathrm{q} / \mathrm{ha}$ on small size and $11.13 \mathrm{q} / \mathrm{ha}$ on marginal size farms and on an average, it was $9.14 \mathrm{q} / \mathrm{ha}$. On the whole, the estimated value of Index of Realized Potential Farm Yield (IRPFY) was found to be 85.63 per cent, whereas the Index of Realized Potential Yield (IRPY) was observed as $69.52 \%$. An overall Index of Yield Gap was estimated as $30.48 \%$. It may be inferred from the study that the proper utilization of recommended package and practices of aromatic rice along with the supply of quality inputs viz. seeds, fertilizers, irrigation and plant protection measures on different categories of farms may help reduce the yield gap of the crop on the one hand and raise the income of the farmers on the other.

\section{Introduction}

Rice Research to increase rice productivity and value for the poor and helps rice farmers adapt to climate change. Rice Research delivers the benefits and promotes all the advancements in the field of rice science to the farmers. Rice accounts for a significant contribution to the total food grain production in India. As the rice production area either stabilizes or declines and there is a wide gap between projected demand and current level of production, vertical growth in production through rice is a practically feasible and adoptable technology. This paper attempts to elucidate the current scenario, strategies and agro-techniques for seed as well as grain production, quality parameters and economic aspects of rice in Chhattisgarh. The enhancement in rice production has been mainly due to high yielding varieties, while 
harvested rice area for the corresponding period has expanded from $31 \mathrm{~m}$ ha to about 44 $\mathrm{m}$ ha, accounting for only 42 percent increase. However, to maintain the present level of selfsufficiency, India needs to produce 115 million tonnes of rice by the year 2020 which can be brought either by horizontal or vertical expansion (Department of Agriculture, GOI, 2011).

Rice is a staple food crop and it constitutes over half of the cereals consumption of the country (Bharati et al., 2014; Ali, 2008). It contributed 95.32 million tonnes (39.46 percent) of the total food grain production (241.56 million tonnes) in the country in 2010-11 (Singh et al., 2014). India stands first in paddy area with over 43 million hectares and second in its production. In spite of dietary diversification and shift of consumers' preferences towards horticultural and livestock products, rice is playing a seminal role in food security of the country as it is a rich source of energy (Singh and Singh, 2000). The total domestic demand for rice is estimated to be 113.3 million tonnes and requires $28-29 \%$ yield enhancement to achieve 2.65 tonnes per hectare average yield for the year 2021-22 (Kumar et al., 2009). Notwithstanding the fact that technological breakthrough in the field of agriculture has resulted in increased crop productivity, trials and demonstrations are conducted to test feasibility and suitability of new technologies before releasing them for adoption on farmers' field, the crop yield realized on the farmers' field are considerably lower than that recorded on the demonstration plot (Chaudhary, 2000; Ali, 2008). It was felt that as a step towards narrowing down the yield gap between the farmers' field and the demonstration plots, there was a need to take up in-depth analysis of yield (Chavan et al., 2008; Fale et al., 1985; Gaddi and Mundinamani, 2002; Gaddi et al., 2002). The objectives of the study were: To estimate the yield gap with respect to rice production and to measure the gap between recommended package of practices and actual farmers' practices with respect to Jeeraphool rice production.

Studies on domestic trade in aromatic rice have not received considerable attention in India despite the fact that scented rice varieties have competitive international price and the country can earn foreign exchange from them. Chhattisgarh has traditionally been known as the bowl of scented rice in central India, particularly due to several varieties of its aromatic rice (Marothia, 2003). In recent years, there has been a serious concern among the farmers, scientists, policymakers and environmentalists regarding continuous erosion of genetic biodiversity of rice cultivars (Singh et al., 2000; Singh and Singh, 2003).

India has a rich and wide range of genetic wealth of rice. It has been estimated from various surveys that nearly 50,000 of rice is still being grown in the country (Patra, 2000). With the introduction of high yielding varieties and new technologies become a great threat to the security of the age-old practice of growing traditional varieties and landraces which may have immense potential for different important traits (Prakash et. al., 2007).

\section{Materials and Methods}

The study is based on both primary as well as secondary data. Nine villages were selected for the study of yield gap in aromatic/scented rice variety Jeeraphool during the year 201718 at Batauli block of Surguja district in Chhattisgarh. It was purposively selected for the study on account of productivity of Jeeraphool rice in the geographical area of Surguja. Out of seven block in the district, Batauli block was selected based on larger area of Jeeraphool rice cultivation.

Further nine villages were selected for data 
collection (Table 1). A sample of 30 farmers, constituting 10 marginal, 5 big and 15 small farmers were selected by using probability proportional to size (PPS) method. Data were collected by Krishi vigyan Kendra, Indira Gandhi Krishi Vishwavidyalaya, Ambikapur, Surguja, Chhattisgarh. It is Situated at N $23^{\circ} 8^{\prime} 22^{\prime \prime}$ latitude, E $83^{\circ} 8$ ' $55^{\prime \prime}$ longitude and altitude of $558 \mathrm{~m}$ above mean sea level.

\section{Yield gap and indices of yield gap}

Yield gap was estimated using methodology developed by the International Rice Research Institute (IRRI) Manila, Philippines. Potential yield $\left(\mathrm{Y}_{\mathrm{P}}\right)$ is defined as the per hectare crop yield realized on the research station. Potential Farm Yield $\left(\mathrm{Y}_{\mathrm{d}}\right) /$ Progressive farmers' yield $\left(Y_{d}\right)$ is the highest yield obtained by a farmer in a farm size category and the Actual Yield $\left(Y_{a}\right)$ is defined as per hectare yield realized by the farmers on their field. The Total Yield Gap (TYG) is computed as the difference between the Potential Yield $\left(\mathrm{Y}_{\mathrm{P}}\right)$ and the Actual Yield $\left(\mathrm{Y}_{\mathrm{a}}\right)$ (Eq.1).

$\mathbf{T Y G}=\mathbf{Y}_{\mathbf{P}}-\mathbf{Y}_{\mathbf{a}}$

[Eq.1]

The Total Yield Gap comprises of Yield Gap I and Yield Gap II.

Yield Gap I (YG I): It is the difference between the Potential Yield $\left(\mathrm{Y}_{\mathrm{P}}\right)$ and Progressive Farmers' yield ( $\left.\mathrm{Y}_{\mathrm{d}}\right)$ (Eq.2).

$\mathbf{Y G} \mathbf{I}=\mathbf{Y}_{\mathbf{P}}-\mathbf{Y}_{\mathbf{d}}$

Yield Gap II (YG II): It is the difference between the Progressive farmers' yield / Potential Farm Yield $\left(\mathrm{Y}_{\mathrm{d}}\right)$ and the Actual Yield $\left(\mathrm{Y}_{\mathrm{a}}\right)(\mathrm{Eq} \cdot 3)$.

$$
\text { YG II }=\left(\mathbf{Y}_{d}-\mathbf{Y}_{\mathrm{a}}\right)
$$

Index of Yield Gap (IYG): It is the ratio of the difference between the Potential Yield
$\left(\mathrm{Y}_{\mathrm{P}}\right)$ and the Actual Yield $\left(\mathrm{Y}_{\mathrm{a}}\right)$ to the Potential Yield ( $\mathrm{Y}_{\mathrm{P}}$ ) expressed in percentage (Eq.4)

$\mathbf{I Y G}=\left[Y_{P}-Y_{a} / Y_{P}\right] \times 100$

Index of Realized Potential Yield (IRPY)

$I R P Y=\left[Y_{a} / Y_{P}\right] \times 100$

[Eq.5]

Where,

$\mathrm{Y}_{\mathrm{a}}=$ Actual yield

$\mathrm{Y}_{\mathrm{P}}=$ Potential yield

Index of Realized Potential Farm Yield (IRPFY)

$\operatorname{IRPFY}=\left[\mathbf{Y}_{\mathrm{a}} / \mathbf{Y}_{\mathrm{d}}\right] \times 100$

[Eq.6]

Where,

$\mathrm{Y}_{\mathrm{a}}=$ Actual yield

$Y_{d}=$ Potential farm yield

\section{Results and Discussion}

In view of topographical structure prevailed in this part of the country, $20-30 \%$ of the rice is grown in low lying areas (Kanhar soil). Normally much irrigation is not required in this soil and one or two irrigation (s) are sufficient to harvest a satisfactory production during normal year. This group of soil has further advantage for rice production because water which is applied to upper situation recedes to low lying areas. The water table is also very close to the surface in many places during rice growing season. But at the same time rolling topography of the region encourages the internal drainage of water from low lying areas to the rivers, especially in Kanhar soil, creates water deficits at later growth stage of the rice crop. The long duration rice varieties are generally grown by the farmers in these lands. Perched water table at the surface of the soil for short duration during rice growing season. The farmers are growing either traditional varieties of long duration or medium duration, which are forced 
to go under moisture stress in one stage or the other even during normal years. Weed control and level of fertilizer use are highly correlated with production and growth. Upland rice growth is negatively correlated with slope of the land and soil depths. However, short duration moisture stress especially at tillering and dough stages, weeds and nutrient response causes reduction in upland rice production. Blast and bacterial blight diseases adversely affect seed yield in upland rice.

The biasi (beushening) system of rice cultivation is most widely used in the Batauli block, where optimum plant population is major constraints for achieving higher productivity. However, improved biasi i.e. maintaining plant population must be done to increase yield of rice. Farmers usually grow tall and photo-sensitive varieties, which flower by mid October and mature by mid November. The monsoon starts withdrawing from the northern part by $15^{\text {th }}$ September and has usually completely withdrawn from the entire area around $1^{\text {st }}$ October. Winter conditions set in by mid November, when the average minimum temperature reaches around $15^{\circ} \mathrm{C}$. December and January are the coldest months with minimum temperatures of about $7^{0} \mathrm{C}$. The northern sites of district have longer and more severe winter periods than the southern part of district. Therefore Jeeraphool rice variety were fitted for cultivation in such geography for better quality rice.

The analysis revealed that though the yield gap of $6.75 \mathrm{q} / \mathrm{ha}$ on big farms was quite high. However, on comparison with other farm sizegroups, the yield gap was observed comparatively low on big farms (Table 2) which may probably be due to their better management of farms or their better economic condition which enabled them to use technical inputs required for Jeeraphool paddy cultivation. For in-depth study, the Total Yield Gap was split into two components, viz. Yield
Gap-I and Yield Gap-II. Yield Gap-I was observed to be as high as $8.05 \mathrm{q} / \mathrm{ha}$ on marginal farms followed by $5.45 \mathrm{q} /$ ha and $3.47 \mathrm{q} / \mathrm{ha}$ for small and big farms, respectively. Yield Gap-II was found to be $3.08 \mathrm{q} / \mathrm{ha}$ on marginal farms, whereas 4.10 $\mathrm{q} / \mathrm{ha}$ and $3.28 \mathrm{q} / \mathrm{ha}$ on small and big farms, respectively. It was evident that yield gap decreased as the farm size increased showing inverse relationship between yield gap and farm size. The higher magnitude of Yield Gap-I may probably be attributed to the nontransferable component of technology such as cultural practices like differences in taking up of agronomical practices such as time of preparation of land, maintenance of proper plant spacing and plant density, application of chemical fertilizers and plant protection materials and water in appropriate doses between the research station and farmers' field.

\section{Indices of yield gap}

It may be observed that, on an average, the estimated value of Index of realized potential farm yield was worked out as 85.63 as compared to overall Index of realized potential yield (69.52). However, the farm size wise IRPY (Index of realized potential yield) analysis revealed that it was highest on big farms being 77.50 percent and the lowest on marginal farms with 62.90 percent, indicating that increment in yield may be made to the level of 22.50 and 37.10 percent, respectively (Table 3).

\section{Gap between recommended practices and actual farmers' practices}

The input gap in question has been obtained by deducting the amount of inputs used at the farmers' field from the respective amount of the inputs used at the research station (Gavali et al., 2011). It is evident that Overall gap of 
fertilizer used by the paddy growers in the study area was FYM, Vermi Compost and Organic manure respectively (Table 4). Better economic status of larger farmers may be the reason for such an observation they were used organic manure or optimum dose of fertilizers, plant population and recommended practices viz. selection of seeds, sowing and transplanting method, weed management and plant protection measures. Furthermore, it was observed that plant protection materials were used in excess of recommended doses. It may probably be on account of lack of awareness on the part of rice growers about ill effects of plant protection chemicals on human and animal health and soil microorganisms (Singh et al., 2014).

Technological breakthrough in the field of agriculture has resulted in increased crop productivity; however, the crop yields realized on the farmers' field are considerably lower than that recorded on the demonstration plot (Job, 2006; Kurmi and Bhowmick, 1991). Study revealed that the yield gap decreases with increase in the farm size, showing an inverse relationship between yield gap and farm size. The higher yield gap may be attributed to the non-transferable component of technology such as cultural practices like differences in taking up of agronomical practices such as time of preparation of land, maintenance of proper plant spacing and plant density, application of chemical fertilizers and plant protection materials and water in appropriate doses between the research station and farmers' field (Raju et al., 1996; Reddy, 1997; Sahu et al., 1993; Sananse, and Vichare, 2007). On an average, the total yield gap of Jeeraphool rice was estimated to be $9.14 \mathrm{q} / \mathrm{ha}$. The yield gap may also be attributed to the gap in inputs use between the recommended package and practices as well as farmers' practices.

Table.1 Selected villages under the study

\begin{tabular}{|l|l|l|l|}
\hline Sr. & Villages & No. of H.H. & Population \\
\hline $\mathbf{1}$ & Nakna & 310 & 1358 \\
\hline $\mathbf{2}$ & Telaidhar & 573 & 2340 \\
\hline $\mathbf{3}$ & boda & 258 & 1821 \\
\hline $\mathbf{4}$ & Maheshpur & 423 & 2475 \\
\hline $\mathbf{5}$ & Bataikela & 423 & 1874 \\
\hline $\mathbf{6}$ & Dhekidoli & 191 & 1183 \\
\hline $\mathbf{7}$ & Lalati & 205 & 1075 \\
\hline $\mathbf{8}$ & Taragi & 203 & 907 \\
\hline $\mathbf{9}$ & Jarhadih & 153 & 706 \\
\hline
\end{tabular}

Table.2 Yield gap in Aromatic rice (Jeeraphool) on sample farms (Yield q/ha)

\begin{tabular}{|l|l|l|l|l|l|l|}
\hline $\begin{array}{l}\text { Farm size } \\
\text { group }\end{array}$ & $\begin{array}{l}\text { Potential } \\
\text { yield }\left(\mathrm{Y}_{\mathrm{p}}\right)\end{array}$ & $\begin{array}{l}\text { Progressive } \\
\text { farmers' } \\
\text { yield }\left(\mathrm{Y}_{\mathrm{d}}\right)\end{array}$ & $\begin{array}{l}\text { Yield Gap I } \\
\text { (YG-I) }\end{array}$ & $\begin{array}{l}\text { Actual } \\
\text { farmers, } \\
\text { yield }\left(\mathrm{Y}_{\mathrm{a}}\right)\end{array}$ & $\begin{array}{l}\text { Yield Gap II } \\
\text { (YG-II) }\end{array}$ & $\begin{array}{l}\text { Total Yield } \\
\text { Gap (YG-I } \\
\text { + YG-II) }\end{array}$ \\
\hline Marginal & 30 & 21.95 & 8.05 & 18.87 & 3.08 & 11.13 \\
\hline Small & 30 & 24.55 & 5.45 & 20.45 & 4.10 & 9.55 \\
\hline Big & 30 & 26.53 & 3.47 & 23.25 & 3.28 & 6.75 \\
\hline Overall & 30 & 24.34 & 5.66 & 20.86 & 3.49 & 9.14 \\
\hline
\end{tabular}


Table.3 Indices of yield gap in rice (Jeeraphool) on sample farms

\begin{tabular}{|c|c|c|c|}
\hline Farm size & $\begin{array}{l}\text { Index of Realized } \\
\text { Potential Yield (IRPY) }\end{array}$ & $\begin{array}{c}\text { Index of Realized } \\
\text { Potential Farm Yield (IRPFY) }\end{array}$ & $\begin{array}{c}\text { Index of } \\
\text { Yield Gap (IYG) (\%) }\end{array}$ \\
\hline Marginal & 62.90 & 85.97 & 37.10 \\
\hline Small & 68.17 & 83.30 & 31.83 \\
\hline Big & 77.50 & 87.64 & 22.50 \\
\hline Overall & 69.52 & 85.63 & 30.48 \\
\hline
\end{tabular}

Table.4 Intervention practices of the KVK, Ambikapur, Surguja

\begin{tabular}{|l|l|l|l|}
\hline Sr. & Practices & Farmers' practices & Recommended Practices \\
\hline $\mathbf{1}$ & Selection of Seeds & Old and Mixed seed & Purified Seed \\
\hline $\mathbf{2}$ & Plant Population & High density & Optimum density \\
\hline $\mathbf{3}$ & $\begin{array}{l}\text { Date of Sowing and } \\
\text { Transplanting }\end{array}$ & Too late & Timely showing \\
\hline $\mathbf{4}$ & Sowing Method & $\begin{array}{l}\text { Broadcasting and Randomly } \\
\text { transplanting }\end{array}$ & Line Transplanting \\
\hline $\mathbf{5}$ & Fertilizer & No. fertilizer & $\begin{array}{l}\text { FYM, Vermi Compost and } \\
\text { Organic manure }\end{array}$ \\
\hline $\mathbf{6}$ & Weed management & No / late / Hand weeding & $\begin{array}{l}\text { 2-3 time paddy weeder in 15 } \\
\text { days interval. }\end{array}$ \\
\hline $\mathbf{7}$ & Plant Protection & Improper & $\begin{array}{l}\text { Timely and used of organic } \\
\text { product (Neem product) }\end{array}$ \\
\hline
\end{tabular}

In conclusions, the major emphasis in rice research over past few decades has been given on the development of technology for irrigated ecosystem, which has resulted in higher productivity. Most of the farmers with extensive poverty in Surguja dominated by rainfed ecologies where rice is the principal source of staple food, employment, and income for the rural population. Success has been limited in increasing productivity in rainfed rice systems. Rice yields in these ecosystems home to 80 farmers who farm a total of 60 ha. remain low at 1.0 to 2.5 tonnes/ha, and tend to be variable due to erratic monsoons. Similar is the condition for submergence, problem soils, and other abiotic stresses. Technological innovations are also required for production of high quality seed, development of appropriate varieties and agronomic practices for specific ecosystems, new management practices for control of diseases, insects and pests including weeds. Farm mechanization, particularly for smaller holdings need attention. Proper storage, postharvest handling and value addition have been the neglected areas of research.

On an average, the total yield gap of Jeeraphool rice was estimated to be $9.14 \mathrm{q} / \mathrm{h}$. The yield gap may also be attributed to the gap in inputs use between the recommended package and practices as well as farmers' practices. To minimize the yield gap, some measures like, provision of assured electricity supply, subsidized diesel for irrigation, expansion of surface irrigation (Canal as low cost irrigation method), effective credit facility, effective implementation of crop insurance scheme as well as minimum support prices, along with arrangement for 
supply of quality seed, fertilizers, insecticides and pesticides etc. to farmers on time are required (Singh and Kumar 2000; Swathi, and Chandrakandan, 2006). They would also require effective extension services to enable them to use recommended level of inputs (Singh, 2010).

\section{References}

Ali N. 2008. Rice yield gap in West Bengal: Scale and Factors Accountable. Agricultural Situation in India 64 (12): 625-629.

Bharati RC, Singh KM, Chandra N and Singh AK. 2014. Economic Condition of Eastern Region of India-A Statistical Evaluation. Journal of Agri Search; 1(3):173-179.

Chaudhary RC. 2000. Strategies for bridging the yield gap in rice: A Regional Perspective for Asia. International Rice Commission News 49: 22-31.

Chavan AP, Mandavkar PM and Sagvekar VV. 2008. Performance of frontline demonstration in transfer of technology under paddy groundnut cropping system in South Konkan region of Maharashtra. Journal of Farming System Research and Development 14 (1): 129-131.

Fale JB, Thakare GG and Borude SG. 1985. An economic analysis of yield gap in rice in Ratnagiri district. Agricultural Situation in India 39 (12): 925-929.

Gaddi G Mundinamani SM and Basavaraj $\mathrm{H}$. 2002. Yield gaps and constraints in the production of rabi sorghum in Karnataka: a path coefficient analysis. Agricultural Economics Research Review 15 (1): 13-25.

Gaddi GM and Mundinamani SM. 2002. Yield Gaps, Constraints and potential in cotton production in North KarnatakaAn Economic analysis. Indian Journal of Agricultural Economics 57 (4): 722734.
Gavali AV, Deokate TB, Choudhari RB and Kamble BH. 2011. Yield gap analysis of Jowar in Maharashtra. Agricultural Economics Research Review 24 (2): 339-343.

GOI, Department of Agriculture, 2011, New Delhi.

Job E. 2006. Yield gap of rice in Alppuzha district of Kerala. Journal of Tropical Agriculture 44 (1\&2):88-90.

Kumar A, Sinha DK, Mishra RR, Ahmad N and Singh KM. 2015. Yield gap analysis of hybrid rice: A case study in Kalyanpur block of Samastipur district (Bihar). Journal of Agri. Search 2 (4): 273-276.

Kumar P, Joshi PK and Birthal PS. 2009. Deemed projections for food grains in India. Agricultural Economics Research Review (22): July-December, 237-243.

Kumar, L.R., Shrinivas, K., Singh, S.R.K. 2005. Technical Efficiency in Rice Farms under Irrigated Conditions of Northwest Himalayan Region- A NonParametric Approach. Indian journal of Agricultural Economics. 60, 483-493.

Kurmi P and Bhowmick BC. 1991. Studies in yield gap of rice in Assam. Economic Affairs 36 (3): 188-192.

Marothia, D. K. (1997) Agricultural technology and environmental quality: An institutional perspective - Keynote paper. Indian Journal of Agricultural Economics, 52 (3): 473-487.

Marothia, D. K., (2001) Agricultural development in Chhattisgarh: Policy issues (Chhattisgarh main Krishi Vikas: Nitigat Pahlu - in Hindi). Paper presented in a Workshop jointly organized by Indira Gandhi Agricultural University and Chhattisgarh Farmers Commission at Raipur, Feb.26, pp.7.

Marothia, D. K., (2003) Domestic trade in aromatic rice: Lessons from an exploratory study of Chhattisgarh In: A Treatise on the Scented Rices of India. 
Eds: R. K. Singh and U. S. Singh. Ludhiana \& New Delhi: Kalyani Publishers. pp. 189-210.

Marothia, D.K., Singh, R.K., Chandrakar, M.R. and Jain, B.C. 2007. Economics and marketing of aromatic rice- A case study of Chhattisgarh. Agricultural Economics Research Review. JanuaryJune, pp. 29-46.

Patra, B.C., 2000. Collection and characterization of rice genetic resources from Keonjhar district of Orissa. Oryza 34:324-326.

Raju VT, Reddy GR and jainath A.1996. An economic analysis of yield gaps and constraints in rice production in Guntur district of Andhra Pradesh. Journal of Research ANGRAU 24 (1\&2): 106-111.

Reddy GR.1997. Differential performance of high yielding rice varieties yield gaps and constraints. Crop research Hisar 14 (2): 337-346.

Sahu RM, Sarawagi AK and Bishen PK. 1993. Yield gap analysis of paddy production in Jabalpur district of Madhya Pradesh. JNKVV-Research Journal 27 (1): 71-76.

Sananse SL and Vichare. 2007. Yield gap analysis of rice based cropping system in North Konkan coastal Agroecosystem of Maharashtra. Agricultural Situation in India 64 (1): 7-15.
Singh BK and Kumar P.2000. Systematic approach of yield gap analysis in rice production in Ranchi district. Journal of Research BAU. 12 (1): 1-6.

Singh KM and Singh RKP. 2000. Rice in Bihar-An Economic Analysis with Special Reference to Boro Rice. Agricultural Situation in India, 56 (11): 677-682.

Singh KM, Singh RKP and Kumar A. 2014. Adoption of Modern Agricultural Technologies in Bihar: A Farm Level Study. Environment \& Ecology 32(4): 1342-1346.

Singh M. 2010. Yield gap and constraints in rice production in India. Agricultural Situation in India 67 (2): 69-74.

Singh, R. K. and U.S. Singh (2003) A Treatise on the Scented Rices of India. New Delhi: Kalyani Publishers.

Singh, R. K., U.S. Singh and G.S. Khush, (2000) Aromatic Rices. New Delhi: Oxford and IBH Publishing Company. Pvt Limited.

Sitadevi, K., Ponnarsi, T. 2009. An Economic Analysis of Modern Rice Production Technology

Swathi PS and Chandrakandan K. 2006. Yield gap analysis among rice growers in north eastern zone of Tamil Nadu." Agricultural Situation in India 62 (11):729-733.

\section{How to cite this article:}

Ravindra Tigga and Satyapal Singh. 2018. Yield Gap Analysis of Jeeraphool Rice in Batauli Block of Surguja. Int.J.Curr.Microbiol.App.Sci. 7(12): 907-914.

doi: https://doi.org/10.20546/ijcmas.2018.712.113 